Ragia Mohamed Ali shelih

\title{
An Analytical Study for the relationship between Securitization Gain Fair, Value Accounting and Earnings \\ Management \\ Ragia Mohamed Ali shelih
}

\begin{abstract}
:
Purpose -The main purpose of the research is to examine the impact of fair value accounting rules on asset securitization, through determining whether managers use discretion afforded by fair value accounting particularly Level 3 valuations to manage income from securitizations under FAS 140.
\end{abstract}

Design/ Methodology/ Approach - A sample of U.S. bank holding companies is selected during the period 2007-2009 from the Federal Reserve Bank Holding Company Database which have the financial data necessary for data analysis. The research examines the 240 banks/ quarters observations in 2007-2009 when FAS 140 was in effect. A Panel data analysis is employed for testing the research hypothesis to measure different variables for banks over several time periods using STATA software.

Findings-The results show that managers take advantage of the easier criteria of FAS 140 for securitization and use their discretion over fair value accounting rules to pick a lower discount rate to manage income from securitization. Since managers need to use assumptions in calculating the fair value of expected cash flows from the retained portion, they have some discretion in choosing a suitable discount rate in their calculations. Suggesting that there is evidence of earnings management using securitization under FAS 140.

\section{ملخص البحث}

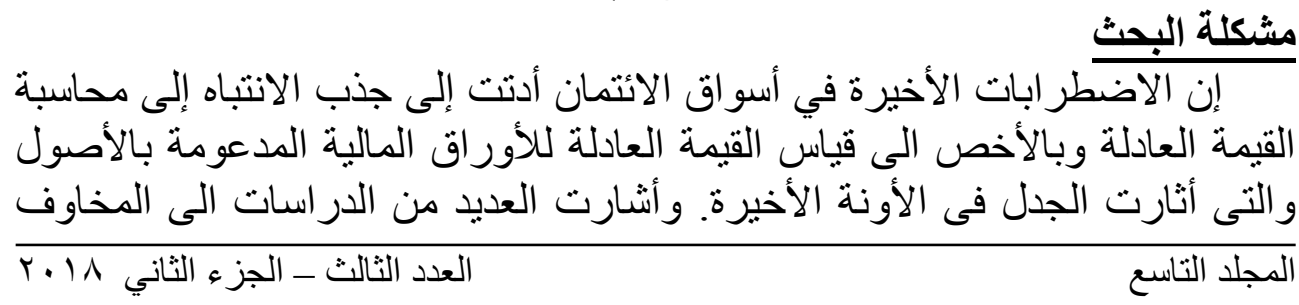


An Analytical Study for the relationship between Securitization Gain Fair...

Ragia Mohamed Ali shelih

المتعلقة بإدارة الأرباح عن طريق الربح الناتج عن التوريق حيث وجد أن المعايير

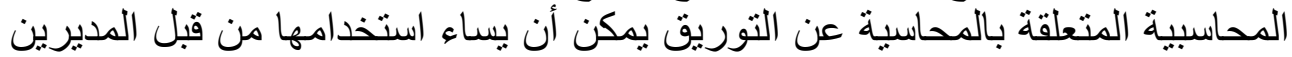

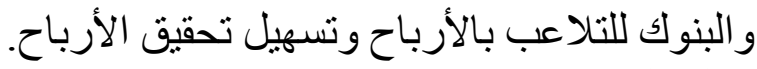

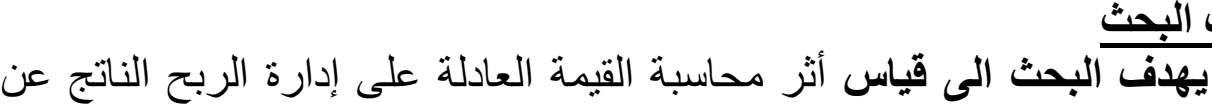

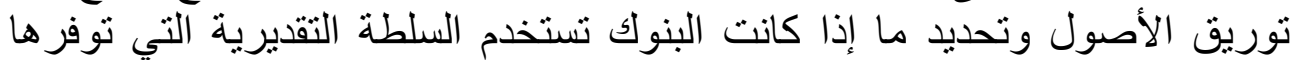

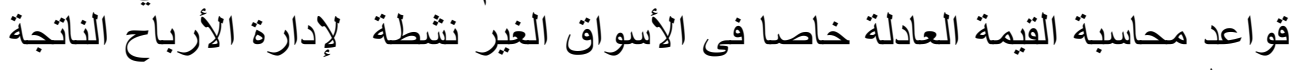

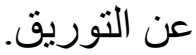

تم اختيار عينة البحث من الثركات القابضة للبنوك فى الولائات المتحدة خلال منهج البحن التوريث

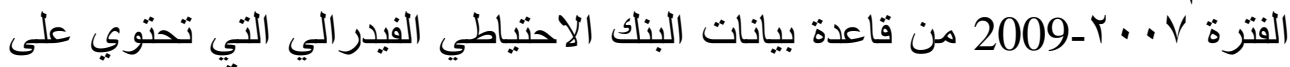

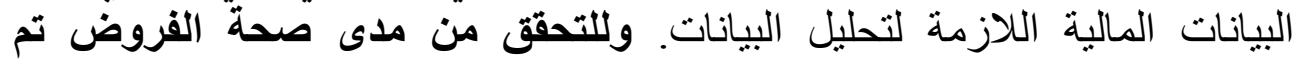
إستخدام السلاسل الزمنية المقطعية " Panel Data Analysis " لاختبار فروض ملته البحث لقياس المتغير ات المختلفة للبنوك خلاسل فتر ات زمنية متعددة باستخدام البرنامج

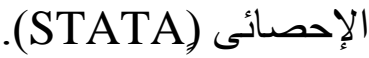
يوجد علاقة سلبية بين محاسبة القيمة العادلة والربح الناتج عن التوريق حيث

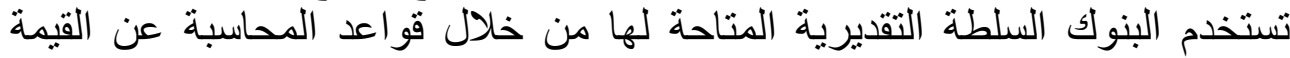
العادلة لإختيار معدل أقل من (discount rate) لزيادة الربح الناتج عن التولة التوريق من

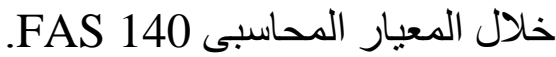

\section{Introduction}

Securitization become prevalent in the USA since the 1980s and in the European Union since early 1990s. The years preceding the financial crisis were characterized by a boom in worldwide securitization markets. The issuance of securitization products more than tripled, from less than $\$ 700$ billion in year 2000 to around $\$ 2800$ billion in year 2006 (Bertay et al., 2017). The US markets increased the total amount of asset backed securitizations between 2004 and 2006 from \$1.9 trillion to 4 trillion dollars (Cerbioni et al., 2015). Between 2000 and 2010, the size of the global securitization market increased from US $\$ 4.8$ trillion to US \$13.6 trillion (Buchanan, 2016).

After a long phase of development, the crisis then caused an effective break down of securitization markets and resulting in 
An Analytical Study for the relationship between Securitization Gain Fair...

Ragia Mohamed Ali shelih

the collapse of worldwide securitization markets. Since then, asset securitizations have received a lot of negative publicity (Briggs and Beams, 2012) and a lot of questions have been raised about the problems inherent in the securitization process (Sarkisyan and Casu, 2013). In the aftermath of this crisis, asset securitizations were criticized by several market participants claiming the opaqueness associated with such activities (Lejard, 2016). So far, securitization is largely unregulated and not well understood (Gorton and Metrick, 2011). As a result, several accounting researchers contributed to this concern by providing further understandings about securitization and its accounting process (e.g., Ryan 2008; Adhikari and Betancourt, 2008).

Senarath (2016) argues that the weaknesses in the accounting rule SFAS 140 applied to securitizations played a major role in the recent economic boom. This resulted in issuing the statement of financial accounting standard SFAS No. 166 "Accounting for Transfers of Financial Assets" as an amendment of the statement of financial accounting standard SFAS No. 140 "Accounting for Transfers and Servicing of Financial Assets" to further regulate gains recognition in securitization transactions.

\section{Rationale of the Research}

1. The accounting treatments for securitization have become a big concern to regulators, investors, academics, and other market participants (Zhang, 2014). Although these financial transactions have been misused over time, the fundamental reasons for their use are continuing. Moreover, since it is not expected that securitization is going to disappear in the coming future; this phenomenon and the evolving rules in this realm must be understood by the accounting and financial professionals and accountants must remain up to date (Briggs and Beams, 2012).

2. Asset securitizations provide a potentially powerful setting in which to study earnings management because gains from securitization require the exercise of judgment and discretion. The use of securitization transactions to meet earnings target via 
An Analytical Study for the relationship between Securitization Gain Fair...

Ragia Mohamed Ali shelih

securitization gain raises concerns regarding the quality of accounting earnings as financial instruments are measured at fair value. Attention should be given to unreliable estimates arising from fair value measurements (Chen and Tseng, 2012).

3. In addition, asset securitizations are an increasingly important economic activity that is in focus in the recent financial crisis, particularly because of the problematic accounting rules that apply to securitizations (Barth and Tylor, 2010). Therefore, even though research on securitization as an earnings management vehicle has attracted the attention of a wide range of audiences, empirical research about its real effect is still limited.

\section{Research Problem}

The recent financial debacle has led to a major debate about fair value accounting hierarchy among accounting and banking regulators, researchers and many others (Sodan, 2015). Bryan and Lilien (2013) indicated that fair value measurement for securitization have been problematic and gained a lot of attention particularly in relation to FAS 140. Several commentators argue that fair value accounting has not lived up to its expectations to increase transparency in financial reporting (Krumwiede, 2008) particularly in relation to Level 3 valuations (Cheng, 2012; Huizinga and Laeven, 2009). The flexibility offered in fair value estimates create opportunities for management to manipulate earnings (i.e.; Cheng, 2012; Fargher and Zhang, 2014).

The likelihood of manager's manipulations to attain their own goals has been subject to various research conducted for understanding whether managers have both incentive and the possibility for earnings management practices under fair value accounting (Tutino and Pompili, 2018). Hence, earnings managements' examination in the banking sector is very essential because of the substantial influence of these problems on the economy (Dantas et al., 2012).

All these concerns have increased during and after the financial crisis era which was accompanied by a strong decline in 
An Analytical Study for the relationship between Securitization Gain Fair...

Ragia Mohamed Ali shelih

bank profitability (Haan and Oordt, 2017). As a result, a lot of questions have been raised about securitization ability to work in an appropriate balanced market environment (Riddiough, 2011). This reason rationalizes the examination of a possible association between earning management practices and the discretional use of unobservable inputs in fair value accounting application in securitization settings.

To summarize, the research problem is related to determining whether managers take advantage of the easier criteria of FAS 140 for securitization and use their discretion over fair value accounting rules to manage earnings.

\section{Research Objectives}

The main objective of the research is to determine the effect of fair value accounting on asset securitization, through determining whether managers use discretion afforded by fair value accounting particularly Level 3 valuations to manage income from securitizations under FAS 140.

\section{Background and Hypothesis Development}

5.1 How Fair Value Accounting Measurements affect Assets Securitizations?

The FASB and the IASB supported the adoption of fair value accounting since they believe that fair value accounting yields relevant financial information (Barlev and Haddad 2003).

FAS No. 157 provides a "fair value hierarchy" that differentiates between three levels of value based on the inputs that are used to measure assets and liabilities and thus indirectly reflect the level of liquidity of those assets and liabilities (Dontoh et al.,2012). Level 1 (Market to Market) the most liquid relies on quoted prices of identical assets traded in active markets (Goh et al., 2015; Freeman et al., 2017). Level 2 relies on observable inputs other than quoted prices for the asset, such as: (a) quoted prices of similar assets traded in active markets, (b) quoted prices for identical/similar assets traded in the markets that are not active. Level 3 (Market to Model) fair value of assets that are not 
An Analytical Study for the relationship between Securitization Gain Fair...

Ragia Mohamed Ali shelih

observable in active markets; relies on unobservable inputs generated from the reporting entity's private information and their best assumptions on the market conditions (Song et al., 2010; Freeman et al., 2017). It has been recognized that value relevance of fair values differs among the three levels, with Level 3 being the least value relevant (Cheng, 2012). Also, the estimation of Level 3 fair value creates opportunities for the exercise of management judgment and intentional bias which can reduce financial reporting quality (Sodan, 2015).

Recent research on fair value measurements revealed that managers use fair value estimates opportunistically (Fargher and Zhang, 2014; Barth et al., 2012b). The global financial crisis fueled the debate over the quality of financial reporting in the banking sector specifically in relation to the application of fair value accounting in inactive markets (Badertscher et al., 2012).

Critics argue that fair value accounting provides a very useful mean for earnings management (Huizinga and Laeven, 2009; Kolev, 2009; Dechow et al., 2010; and Fargher and Zhang, 2014).

The central of the debate is the degree of discretion allowed by SFAS 157. The greater the level, the less observable and the more discretionary (Cheng, 2012). Laux and Leuz (2010) document that during the financial meltdown banks shifted billions of dollars of assets measured at fair value from level 1 into level 3 to avoid recognizing impairments (Fargher and Zhang, 2014). Academic researchers indicate that Level 3 is subject to significant measurement errors (Freeman et al., 2017). Based on the presence of manger's discretion over Level 3 estimates, managers might attempt to use Level 3 estimation to overestimate earnings and asset values (Goh et al., 2015). Level 3 is associated with estimation uncertainty which provide managers with discretion opportunities to manipulate earnings (Song et al., 2010; Cheng, 2012; Laux and Leuz, 2009).

العدد الثالث - الجزء الثاني ب 1 ب r

المجلد التاسع 
An Analytical Study for the relationship between Securitization Gain Fair...

Ragia Mohamed Ali shelih

Paolucci (2016) provide evidence that Level 3 valuations can be manipulated because their determination is based on management estimations which are subject to their opportunistic decisions. Accordingly, the discretionary nature of fair value accounting should not be ignored, and the real effects of this issue should be taken into consideration by the standard-setting bodies (Cheng, 2012). These shortcomings in fair value accounting rules can negatively affect accounting for assets securitization which also is blamed for triggering the recent financial crises and received a lot of criticism particularly in relation to the accounting rules under FAS 140 (Senarath, 2016).

As it allows banks to establish SPEs, de-recognize the transferred assets, and hold retained interest in the transferred assets. Thus, it is very hard for investors to determine the fair value and risk in their investment (Sun, 2015).

For asset backed securities quoted prices in active markets may not be available, in this case Level 3 valuations may be necessary for the retained interests in the securitizations (Krumwiede et al., 2008; Ryan, 2008). The fair value measurements of retained interests have effects on the amounts of the gain on sale. As a result, the banks may report higher gains on sale by overestimating the fair value measurement of retained interests. Thus, the accuracy of bank's securitization gains is depending on its ability to estimate the fair value of retained interests (Kusano, 2011). Since most of the deficiencies is related to FAS 140, it is expected to be eliminated after the application of FAS 166 that served to move many retained interests from the Level 3 class to the Level 2 inputs class (Freeman et al., 2017).

\subsection{Hypotheses Development}

\subsubsection{The Impact of Fair Value Accounting Rule on Earnings Management Incentives through Securitization Gain}

Prior studies revealed that incentives to meet earnings targets lead managers to make accounting choices that can assist them in meeting or beating those targets. For earnings management

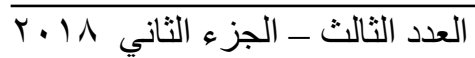
المجلد التاسع 
An Analytical Study for the relationship between Securitization Gain Fair...

Ragia Mohamed Ali shelih

incentives, larger managerial discretion in determining fair value increases managers opportunities to manipulate earnings, which in turn weaken earnings informativeness (Fargher and Zhang, 2014).

Hence, managers can use the discretion allowed in fair value accounting rules opportunistically through reporting higher securitization gains.

Banks use securitization gain to increase earnings through aggressively estimating the fair value of the retained components. Thus, earnings management objectives can be achieved through biased valuation of retained interests from securitized assets (Chen and Tseng, 2012). According to Zhang (2014) the amount of securitization gain can be determined by calculating the difference between the fair value and book value of the components sold and components retained. Where the fair value of the components sold is usually equal to selling price, the fair value of the components retained is based on managerial estimations.

Since the valuation of retained interests directly and completely determines securitization gain (Ryan et al., 2016), then an increase in the fair value of the retained interests will result in an increase in the value of the gain, and in earnings management practices (Kolsi and Matoussi, 2012). This suggests that both the value of the beneficial interests and securitization gains are largely discretionary (Kolsi and Matoussi, 2012). The accounting rules for securitizations under the financial accounting standard FAS 140, give managers considerable discretion over the size of the reported gains from securitizations. This discretion comes in part from ambiguity in the accounting rules over what is meant by "fair value" as well as discretion over the discount rates.

The fair value measurement of the beneficial interests is considered the most difficult and challenging because it is usually measured using Level 3 valuations where no active 
An Analytical Study for the relationship between Securitization Gain Fair...

Ragia Mohamed Ali shelih

market exits and is based on managers' assumptions and estimation of internal models (Ryan, 2008; Dechow et al., 2010; Freeman et al., 2017). These assumptions are unlikely to be realistic, the sensitivity of the results to changes prepayment rates, or discount rates may be underestimated.

This study suggests that when banks have incentives to report opportunistically (e.g. Low pre-securitization earnings or negative change in pre-securitization earnings), they are more likely to use the discretion available when measuring Level 3 inputs to enable them to boost their reported income (Yao et al., 2018). However, after the application of the financial accounting standard FAS 166 most of the beneficial interests arising from securitization are being measured using Level 2 valuations instead of Level 3 valuations (Freeman et al., 2017).

This study hypothesizes that FAS 140 accounting rule for securitization encourages banks to use the discretion afforded by level 3 valuations of retained interests to pick a lower discount rate with an aim to obtain higher securitization gains. Accordingly, the third hypothesis can be developed as follows:

H1: banks use their discretion to choose lower discount rates to obtain higher securitization gains in under SFAS 140.

\section{Methodology}

\subsection{Sample Selection}

The research focuses on U.S. bank holding companies (BHC) with reported total assets greater than $\$ 10$ billion. This study focuses on asset securitization of bank holding companies for several reasons. First, banks operate in a regulated industry and their financial reporting of securitizations is considerably more homogenous than other firms in different industries (Cheng et al., 2011). Second, by focusing on the banking industry, concerns related to data availability are mitigated. Unlike banks, firms in other industries differ significantly in the degree to which they present complete securitization information. Third, banks are the primary securitizers of assets. Finally, compared to financial 
An Analytical Study for the relationship between Securitization Gain Fair...

Ragia Mohamed Ali shelih

report data, banks' public quarterly regulatory reports contain detailed and standardized data about their securitizations (Ryan et al., 2016).

All banks are either listed on New York Exchange NYE or NASDAQ stock market. All financial data is collected from the quarterly financial reports of the Consolidated Financial Statements for Bank Holding Companies (BHCs) FR Y- 9C, filed to the Chicago Federal Reserve System, and from 10-Qs filed with the Securities and Exchange Commission (SEC). All data about securitization and earnings management incentives variables are hand collected from both schedules HC-I "Income Statement" and HC-S "Servicing, Securitization, and Asset Sale Activities" of the Y-9C financial reports.

The research uses a sample of 20 bank holding companies that covers a period of 3 years from the quarter ending March 31, 2007 up to the quarter ending December 31, 2010. This lead to a sample of 240 bank/quarter observations with non-missing variables representing FAS 140.

\subsection{Variables Measurement}

This section explains how each independent variable is measured. All the variables used in the study are bank and time specific and the resulting dataset is a time-series, balanced panel data.

\subsubsection{The Discount Rate}

The research examines whether managers use their discretion to choose lower discount rate to report higher securitization gain. According to Dechow et al. (2010), managers use desirable discount rates in the estimation of fair-value accounting to smooth earnings, this research investigates whether managers' discretion on discount rates plays any role in achieving earnings management incentives.

Thus, when estimating the fair value of the retained interest, managers might choose a lower discount rate to show higher fair value and higher gain on securitization. The discount rate used in 
An Analytical Study for the relationship between Securitization Gain Fair...

Ragia Mohamed Ali shelih

estimating the fair value of the retained interest is used as a proxy for fair value accounting and is considered as the dependent variable.

\subsubsection{Securitization Gain}

The research hypothesis deal with the use of securitization gains (GOS) which is net securitization income for bank as the independent variable.

\subsubsection{Earnings Management Incentives}

The research hypothesis deal with earnings management incentives as the independent variables. As mentioned earlier and consistent with prior studies (e.g., Dechow et al., 2010; Ibrahim, 2010; Chen and Tseng, 2012) earnings before securitization as a proxy for earnings management (EBS) which is the difference between net income for the current quarter and the securitization income for the same quarter.

\subsubsection{The Control variables}

Based on prior studies and besides the variables mentioned in the hypotheses, the size of the off-balance sheet securitized assets will be used as control variables. Which are: mortgage-backed securities (MBS), consumer backed securities (CONSBS), and commercial backed securities (COMMBS) (Ibrahim, 2010; Chen et al., 2008; Hansel and Krahnen, 2007). GOS should be higher for banks with higher securitization and the amount of gains may differ depending on the different types of securitized loans, since each type of loans have different levels of risk (Hansel and Krahnen, 2007; Chen et al., 2008).

\subsection{Empirical Model}

DR $\mathrm{iq}=\mathrm{B} 1 \mathrm{GOS} \mathrm{iq}+\mathrm{B} 2 \mathrm{EBS} \mathrm{iq}+\mathrm{B} 3$ INT-GOS-EBS iq $+\mathrm{B} 4 \mathrm{MBS} \mathrm{iq}+\mathrm{B} 5 \mathrm{CONSBS} \mathrm{iq}+\mathrm{B} 6 \mathrm{COMMBS} \mathrm{iq}+$ eiq

Where:

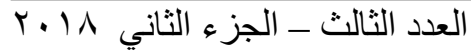

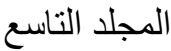


Ragia Mohamed Ali shelih

- DR iq: Discount rate for firm $i$ in quarter $q$ used in the estimation of fair values of assets (Collected from firms 10 $Q$ filed with the SEC).

- GOS iq = Net securitization income for bank $\mathrm{i}$ in quarter $\mathrm{q}$ (from Schedule HI - consolidated income statement);

- EBS iq Earnings before securitization in current quarter = net income for bank $\mathrm{i}$ in quarter q (Schedule HI) less net securitization income during quarter (GOS);

- $\triangle \mathrm{EBS}$ iq $=\mathrm{EBS}$ in current quarter $-\mathrm{EBS}$ in same quarter in prior year;

- INT-GOS-EBS iq= the interaction variable between securitization gain (GOS) and earnings before securitization (EBS)

\section{Control Variables}

- $\mathrm{MBS} \mathrm{iq}=$ Outstanding principal balance of 1-4 family residential loans sold and securitized with servicing retained or recourse or other seller-provided credit enhancements for bank $\mathrm{i}$ in quarter q (Schedule HC-S);

- CONSBS iq = Outstanding principal balance of consumer loans sold and securitized with servicing retained or recourse or other seller-provided credit enhancements for bank $\mathrm{i}$ in quarter q (Schedule HC-S); consumer loans include home-equity lines, credit card receivables, auto loans, and other consumer loans;

- COMMBS iq = Outstanding principal balance of commercial loans sold and securitized with servicing retained or recourse or other seller-provided credit enhancements for bank $\mathrm{i}$ in quarter q (Schedule HC-S); commercial loans include commercial and industrial loans as well as all other loans, leases, and assets;

- $\varepsilon 1 \mathrm{iq}=$ the error term. 
An Analytical Study for the relationship between Securitization Gain Fair...

Ragia Mohamed Ali shelih

\subsection{Data Analysis}

After data collection, data were analyzed using the statistical software STATA. The process of analysis begins with a variety of techniques to obtain results for testing hypotheses. A preliminary analysis is first conducted including descriptive statistics. Then a panel data analysis is employed.

\section{Advantages of Panel data analysis}

1- Panel data can control for individual heterogeneity. Therefore, unlike cross sectional or time series studies, this research will employ panel data analysis techniques that allow for individual company heterogeneity as well as for time effect which could consequently provide different findings.

2- It is more flexible, provide more information in the data, and is associated with less risk of collinearity between variables. This is unlike simple cross section and time series analysis which are associated with high degree of collinearity among variables (Baltagi, 2005 and Brooks, 2014).

3- It can detect and measure the effect of variables which cannot do so in the simple cross section and time series analysis.

4- It allows researcher to create and test more advanced models.

\section{Data Analysis Results}

\subsection{Testing the Research Hypothesis}

The regression model is conducted by using the discount rate (DR) as the dependent variable; securitization gains (GOS), earnings before securitization (EBS); and the interaction variable between GOS \& EBS (Int-GOS-EBS) as the independent variables.

\subsubsection{Assessing Model Goodness of Fit}

Table (1) presents the results of the panel regression analysis. As shown the F-statistic values and the corresponding P-values العدد الثالث - الجزء الثاني ب.11 المجلد التناسع 
An Analytical Study for the relationship between Securitization Gain Fair...

Ragia Mohamed Ali shelih

are less than 0.01. Therefore, it can be concluded that all the three models are significant and effective.

\section{Table (1)}

\section{Panel Regression Results}

DR iq = B1 GOS iq + B2 EBS + B3 INT-GOS-EBS + B4 MBS

+ B5 CONSBS+ B6 COMMBS + siq

\begin{tabular}{|c|c|c|c|}
\hline \multicolumn{4}{|c|}{ FAS $140(2007-2009)$} \\
\hline $\begin{array}{c}\text { Independent } \\
\text { Variables }\end{array}$ & $\begin{array}{c}\text { Random } \\
\text { Effect }\end{array}$ & Fixed Effect & Pooled OLS \\
\hline GOS iq & $\begin{array}{c}-.00007165^{* *} \\
(0.001)\end{array}$ & $\begin{array}{c}- \\
.00007566 * * * \\
(0.001)\end{array}$ & $\begin{array}{c}-.00001267 \\
(0.692)\end{array}$ \\
\hline EBS iq & $\begin{array}{c}-.0000109 * * * \\
(0.000)\end{array}$ & $\begin{array}{c}- \\
.00001146 * * * \\
(0.000)\end{array}$ & $\begin{array}{c}-5.617 \mathrm{e}-06 * * * \\
(0.000)\end{array}$ \\
\hline Int-GOS-EBS & $\begin{array}{c}-8.430 \mathrm{e}-13 * \\
(0.015)\end{array}$ & $\begin{array}{c}-9.113 \mathrm{e}-13^{* *} \\
(0.010)\end{array}$ & $\begin{array}{c}-8.358 \mathrm{e}-13 \\
(0.065)\end{array}$ \\
\hline MBS iq & $\begin{array}{c}-6.641 \mathrm{e}-08^{*} \\
(0.020)\end{array}$ & $\begin{array}{c}-6.508 \mathrm{e}-08 * \\
(0.024)\end{array}$ & $\begin{array}{c}-5.106 \mathrm{e}-0 \\
(0.142)\end{array}$ \\
\hline CONSBS iq & $\begin{array}{c}-1.071 \mathrm{e} 06 * * \\
(0.002)\end{array}$ & $\begin{array}{c}-9.446 \mathrm{e}-07 * * \\
(0.007)\end{array}$ & $\begin{array}{c}-3.061 \mathrm{e}-07 \\
(0.512)\end{array}$ \\
\hline COMMBS iq & $\begin{array}{c}-8.054 \mathrm{e}-08 \\
(0.394)\end{array}$ & $\begin{array}{c}-1.194 \mathrm{e}-07 \\
(0.249)\end{array}$ & $\begin{array}{c}-3.861 \mathrm{e}-07 * * * \\
(0.000)\end{array}$ \\
\hline F-Static & $\begin{array}{l}435.64 \\
(0.000)\end{array}$ & $\begin{array}{l}41.75 \\
(0.000)\end{array}$ & $\begin{array}{l}12.32 \\
(0.000)\end{array}$ \\
\hline
\end{tabular}

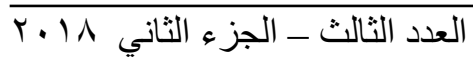


An Analytical Study for the relationship between Securitization Gain Fair...

Ragia Mohamed Ali shelih

Note: Significance at the levels of $10 \%, 5 \%$, and $1 \%$ are indicated by *,**, and ***

\subsubsection{Panel Model Selection}

\subsubsection{Breusch-Pagan Lagrange Multiplier Test (LM)}

To determine whether the OLS or the REM model is appropriate, the Breusch-Pagan Lagrange multiplier test (LM) is conducted. As shown in table (2) the values are significant (Chi$\mathrm{Sq} .=469.23 ; \mathrm{P}<0.01)$. Therefore, the study rejected the null hypothesis in favor of the REM model.

Table (2)

\section{The Summary of Breusch and Pagan Lagrangian Multiplier}

Test

\begin{tabular}{|c|c|}
\hline & FAS 140 (2007-2009) \\
\hline Chi-Sq. Statistic & 469.23 \\
\hline Prob>chi2 & 0.000 \\
\hline
\end{tabular}

\subsubsection{Hausman Test}

Table (3) represents the results of Hausman. The values for the Pre-FAS166 are (Chi-Sq.= 11.61; P > 0.05). Therefore, the study rejects the null hypothesis in favor of the FEM.

Table (3)

The Summary of Hausman Test

\begin{tabular}{|c|c|}
\hline & FAS 140 \\
\hline Chi-Sq. Statistic & 11.61 \\
\hline Prob>chi2 & 0.0405 \\
\hline
\end{tabular}

According to the results of table (2) and (3) it can be concluded that the FEM is the appropriate method for testing the research hypothesis. 
An Analytical Study for the relationship between Securitization Gain Fair...

Ragia Mohamed Ali shelih

Results presented in Table (4) shows the results of equation (1). The fixed effect column shows the coefficients and p-values including discount rate as the dependent variable.

The findings revealed that the discount rate is negatively and significantly associated with GOS (B1=-.00007566, p<0.001), EBS (B2=-.0000109, $\mathrm{P}<0.001)$, and INT-GOS-EBS (B3=9.113e-13, $\mathrm{p}<0.05)$. These findings provide evidence that managers use their discretion in fair value rules to pick a lower discount to obtain higher securitization gains. Therefore, H1 is accepted.

In summary, this empirical evidence supports $H 3$ of the research stating that banks use their discretion to choose lower discount rates to obtain higher securitization gains under FAS 140.

Table (4)

Fixed Effects Panel regression results

$\mathrm{DR}$ iq $=\mathrm{B} 0+\mathrm{B} 1 \mathrm{GOS} \mathrm{iq}+\mathrm{B} 2 \mathrm{EBS}+\mathrm{B} 3$ INT-GOS-EBS+

$\mathrm{B} 4 \mathrm{MBS}+\mathrm{B} 5 \mathrm{CONSBS}+\mathrm{B} 6 \mathrm{COMMBS}+\varepsilon i \mathrm{q}$

\begin{tabular}{|c|c|}
\hline \multicolumn{2}{|c|}{ FAS 140 (2007-2009) } \\
\hline Independent Variables & Fixed Effect \\
\hline GOS iq & $-.00007566^{* * *}$ \\
\hline EBS iq & $(0.001)$ \\
\hline Int-GOS-EBS & $-.00001146^{* * *}$ \\
& $(0.000)$ \\
\hline MBS iq & $-9.113 e-13 * *$ \\
& $(0.010)$ \\
\hline
\end{tabular}

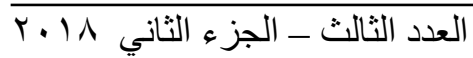


An Analytical Study for the relationship between Securitization Gain Fair...

Ragia Mohamed Ali shelih

\begin{tabular}{|c|c|}
\hline CONSBS iq & $-9.446 \mathrm{e}-07 * *$ \\
& $(0.007)$ \\
\hline COMMBS iq & $-1.194 \mathrm{e}-07$ \\
F-Static & $(0.249)$ \\
& 41.75 \\
& $(0.000)$ \\
\hline
\end{tabular}

Note: Significance at the levels of $10 \%, 5 \%$, and $1 \%$ are indicated by ***, and ***

\section{Conclusions, Contributions, and Future Research \\ 9.1 Conclusions}

The research investigates whether managers take advantage of the easier criteria of FAS 140 for securitization and use their discretion over fair value accounting rules to manage earnings. The results of the study revealed that managers use the discount rate as a tool to manage earnings when banks retain partial interest in a securitized asset. Since managers need to use assumptions in calculating the fair value of expected cash flows from the retained portion, they have some discretion in choosing a suitable discount rate in their calculations. Suggesting that there is evidence of earnings management using securitization under FAS 140.

\subsection{Research Contribution}

With all the lessons learned from the recent crisis, it can be concluded that most of the criticism pointed to fair value accounting rules FAS 157 especially in relation to level 3 valuations should be directed toward securitization accounting rule FAS 140 which allowed for de-consolidation and derecognition of securitization transactions. This research supports the FASB's (2009) decision to mandate the consolidation of offbalance sheet securitization activities to avoid substantial offbalance sheet activities obscuring the firms' true underlying 
An Analytical Study for the relationship between Securitization Gain Fair...

Ragia Mohamed Ali shelih

value. Moreover, although securitization has been considered a key enabler of the financial meltdown, its value as a superior financial tool, along with the necessary control of its application and imperative use of redefined regulations in the FAS 166 cannot be denied.

\subsection{Recommendations for Future Research}

1- Future research can extend this study by examining this relationship among different sectors in addition to banking sector which will further improve the understanding of implications, limitations and ramifications of applying the financial accounting standard FAS 166 in securitization transactions.

2- A comparative study across different countries would be a valuable aim for further research to examine companies that are engaged in securitization transactions under both U.S GAAP and the international financial reporting standards (IFRS) and determining the possibility of earnings management using securitization transactions across companies operating under different legal regimes.

\section{$\underline{\text { References }}$}

- Adhikari, A., and Betancourt, L. 2008. Accounting for Securitizations: A Comparison of SFAS 140 and IASB 39. Journal of International Financial Management and Accounting Vol.19 (1).

- Baltagi, H. 2008. Econometric Analysis of Panel Data, 4th Edition, John Wiley \& Sons Ltd, Sussex.

- Barth. M., and W.R. Landsman. 2010. How Did Financial Reporting Contribute to the Financial Crisis? European Accounting Review 19 (3), pp: 399-423.

- Barth, M. E., J. Biscarri, R. Kasznik and G. Lopez-Espinosa. 2012b. Fair Value Accounting, Earnings Management and the Use of Available-for-Sale Instruments by Bank Managers. Working paper, Stanford University.

- Badertscher, B., Burks, J., and Easton, P. 2012. A Convenient Scapegoat: Fair Value Accounting by Commercial Banks during the 
An Analytical Study for the relationship between Securitization Gain Fair...

Ragia Mohamed Ali shelih

Financial Crisis. The Accounting Review: January 2012, Vol. 87, (1) pp: 59-90.

- Barlev, B. and Haddad, J.R. 2003. Fair Value Accounting and the Management of the Firm. Critical Perspectives on Accounting .Vol. 14, pp: 383-415.

- Briggs, J., and Beams, J. 2012. Asset Securitization in a Changing Environment. The CPA Journal, Vol.82 (9).

- Bryan, S., Lilien, S., and Sarath, B. 2010. Countering Opportunism in Structuring and Valuing Transactions: The Case of Securitizations. Journal of Accounting, Auditing, and Finance. Vol. 25 (2) pp: 289-321.

- Bertay, A., and Gong, D. 2014. Securitization, Financial Stability and Macroeconomy: Evidence from an international panel. Working Paper.

- Bertay, A., Gong, D., Wagnere, W. 2017. Securitization and Economic Activity: The credit Composition Channel. Journal of Financial Stability.Vol.28, pp.225-239.

- Brooks, C. 2014. Introductory Econometrics for Finance (3rd Edition ed.). Cambridge: Cambridge University Press.

- Buchanan, B.G., 2016. Securitization: a Financing Vehicle for All Seasons? Journal of Business Ethics. J Bus Ethics Vol.138, pp559577.

- Cerbioni, F., Fabrizi, M., and Parbonetti, A. 2015. Securitizations and the Financial Crisis: Is accounting the Missing Link? Accounting Forum Vol.39, PP: 155-175.

- Cheng, K. 2012. Accounting Discretion and Fair Value Reporting: A Study of US Banks' Fair Value Reporting of Mortgage-BackedSecurities. Journal of Business Finance \& Accounting, Vol. 39(5), pp.531-566.

- Chen, W., and Tseng, H. 2012. Evidence of Income Smoothing from Securitized Loans and Loan Loss Provisions: Real Transactions vs. Accruals. The International Journal of Accounting Studies. Vol 54 (1), pp:43-75.

- Dantas, J., Medeiros, O., Galdi, F., and Costa, F. 2012. SecuritiesBased Earnings Management in Banks: Validation of a Two-Stage Model. Revista Contabilidade and Finanças, 24 (61), 3754. https://dx.doi.org/10.1590/S1519-70772013000100005.

- Dechow, P., Myers, L., and Shakespeare, C. 2010. Fair Value Accounting and Gains from Asset Securitizations: A Convenient 
An Analytical Study for the relationship between Securitization Gain Fair...

Ragia Mohamed Ali shelih

Earnings Management Tool with Compensation side-benefits. Journal of Accounting and Economics, Vol. 49, pp. 2-25.

- Dechow, P., and Shakespeare, C. 2009. 'Do Managers Time Securitization Transactions to Obtain Accounting Benefits?' The Accounting Review, Vol. 84, No. 1, pp. 99-134.

- Dontoh, A., Elayan, F., Ronen, J., and Ronen, T.2012. Unfair "Fair Value" in an Opaque Credit Default Swap Market: How Marking-toMarket Pushed the International Credit Crunch. SSRN Working Paper. Available at: https://papers.ssrn.com/sol3/papers.cfm?abstract_id=1985833.

- Farghera, N., and Zhang, J. 2014.Changes in the Measurement of Fair Value: Implications for Accounting Earnings. Accounting Forum. Vol. 38, pp. 184-199.

- Freeman,W., Wells,P., and Waytt, A. 2017. Measurement Model or Asset Type: Evidence from an Evaluation of the Relevance of Financial Assets. ABACUS. Volume 53, (2), pp:180-210.

- Gorton,G., and Metrick,A. 2011.Securitization. Working Paper.

- Goh, B., Li, D., Ng, J., and Keng, Y. 2015. Market Pricing of Banks' Fair value Assets Reported under SFAS 157 Since the 2008 Financial Crisis. Journal of Accounting and Public Policy. Vol. 34, (2), pp: 129-145.

- Haan, L., and Oordt, M. 2017. Timing of Banks Loan Loss Provisioning During the Crisis, Journal of Banking and Finance.

- Ibrahim, S. 2010. Servicing Assets and Gain on Securitization under SFAS 156. Working Paper. Available at: http://eprints.kingston.ac.uk/18935/2/Ibrahim-S-18935a.pdf.

- Karaoglu, N. E. 2005. Regulatory Capital and Earnings Management in Banks: The Case of Loan Sales and Securitization. Working Paper, FDIC Center for Financial Research.

- Kolev, K. 2009. Do Investors Perceive Marking-to-Model as Marking-to-Myth? Early Evidence from FAS 157 Disclosure. Working Paper. Available at SSRN: https://ssrn.com/abstract=1336368.

- Kolsi, M., and Matoussi, M. 2012. Do managers use Securitisation Gains for Real Manipulation Purposes? International Journal of Managerial and Financial Accounting. Vol.4, (2).

- Landsman,W., Peasnell,K., and Shakespeare,C. 2008. Are Asset Securitizations Sales or Loans? The Accounting Review, Vol. 83(5), pp. 1251-1272. 
Ragia Mohamed Ali shelih

- Laux, C., and Leuz, C. 2009.The Crisis of Fair-Value Accounting: Making Sense of the Recent Debate. Accounting, Organizations and Society, 34(1), 826-834.

- Lejard, C. 2016. Asset Securitization: characteristics of the Securitized Assets and Wealth Effect for Shareholders. Working Paper.

- Paolucci, E. 2016. Fair Value Accounting and the Financial Crisis: A Literature-based Analysis. Journal of Financial Reporting and Accounting, Vol. 14 (1) pp.1 -16.

- Ryan, S. 2017. Is Banks' Current Regulatory Capital Adequacy the Mechanism by which their Accounting Requirements Affect Financial Stability? Annual Review of Financial Economics. Vol (9,) pp. 1-20.

- Senarath, S. 2016. Securitization and the Global Financial Crisis: Can Risk Retention Prevent Another Crisis? Working paper.

- Šodan, S.2015. The impact of Fair Value Accounting on Earnings Quality in Eastern European Countries. Procedia Economics and Finance. Vol. 32, pp.1769- 1786.

- Song, J., Thomas, W., and Yi, H. 2010. Value Relevance of FAS No. 157 Fair Value Hierarchy Information and the Impact of Corporate Governance Mechanisms. The Accounting Review, Vol. 85, No. 4 pp. 1375-1410.

- Tutino, M., and Pompili, M. 2018. Fair value accounting and management opportunism on earnings management in banking sector: First evidence. Corporate Ownership \& Control. Vol. 15(2).

- Yao, D., Percyb, M., Stewartb, J., and Hub, F. 2018. Determinants of discretionary fair value measurements: the case of Level 3 assets in the banking sector. Accounting and Finance Vol.58, pp:561-597.

- Zhang, 2014 Securitization and Accounting Restatements. Working Paper. Available At: https://papers.ssrn.com/sol3/papers.cfm?abstract_id=2433758. 